\title{
Chemical Composition of the essential oil of Morella parvifolia (Benth.) Parra-0. from the Venezuelan Andes
}

\author{
Mora Flor Dolveni ${ }^{*}$, Silva Bladimiro', Hernández Vanessa1, Rojas Luis Beltran², Carmona Juan' \\ ${ }^{1}$ Departamento de Farmacognosia y Medicamentos Orgánicos, ${ }^{2}$ Instituto de Ciencias Ambientales y Ecológicas, ${ }^{3}$ Instituto de Investigaciones, \\ Facultad de Farmacia, Universidad de Los Andes, Mérida, 5101, Venezuela
}

\section{A B S TR A C T}

\begin{abstract}
Venezuela is a country with high biodiversity. The specie Morella parvifolia belongs to the Myricaceae family, which is rich in essential oils. The study of M. pubescens essential oil is the only reported in this genus. Its major component is germacrene - B ( $32 \%)$. The present work reports the chemical composition of the essential oil of Morella parvifolia (Benth.) Parra -O. collected in Venezuela. The essential oil ( $0.3-0.5 \%$ yield) of the fresh leaves of $M$. parvifolia from three different plants, from the same location, were obtained by hydrodistillation using a Clevenger type apparatus. The chemical constituents were identified by GC-MS analysis. From twenty three to twenty nine compounds $(96.06-97.31 \%$ of the samples) were identified. The major constituents found were $\alpha-$ bisabolol $(50.56-58.9 \%)$ and $\alpha$ - pinene (12.88 -16.79\%). Analysis of antimicrobial activity on Gram (+) and Gram (-) strains was performed but no antibacterial activity was observed.
\end{abstract}

Keywords: $\alpha$-bisabolol; Essential oil; Morella parvifolia; Myricaceae

\section{INTRODUCTION}

Venezuela is among the ten biodiversity-rich countries in the world (UNEP-WCMC, 2010). Therefore, a huge part of this biodiversity still needs to be studied. In the tropical Andes, the paramo is located, usually on the line just above where the cloud forest ends and below the snow line. The paramo is the most biodiverse high mountain ecosystem in the world. The herbaceous paramo formed a heterogeneous array of plant communities, which changes according to local topographic and environmental variations (Jorgensen, 1994; Luteyn, 1999). However, the vegetation has a clear dominance of shrubs and grasses. Morella parvifolia (Benth.) Parra-O. belongs to Myricaceae (Hokche, 2008) family. It is a shrub of almost $4 \mathrm{~m}$ high with leaves and fragrant fruits that grows wild in the Venezuelan Paramo (Parra, 2002). It is commonly known as encinillo.

The essential oil of leaves and fruits of the specie M. pubescens of Colombia has been studied. Fifty-five constituents have been identified and characterized mainly as sesquiterpene hydrocarbons. Germacrene B was the major constituent of the oil also with considerable amounts of selina -3,7-(11)-diene and $\delta$-cadinene (Sandoval, 2010). According to the authors' knowledge the essential oil from the leaves of Morella parvifolia has not been subjected to previous studies. This paper aims to identify the chemical components of essential oil of Venezuela Morella parvifolia and determine its antibacterial activity against Gram (+) and Gram (-) bacteria.

\section{MATERIALS AND METHODS}

\section{Plant material}

Aerial parts of Morella parvifolia were collected at Las Piñuelas, Gavidia, Municipio Rangel, Mérida State, Venezuela. A voucher $\mathrm{N}^{\circ}$ FMBS052 was deposited at Facultad de Farmacia y Bioanálisis Herbarium, Universidad de Los Andes, Mérida, Venezuela (MERF Herbarium).

\section{Isolation of the essential oil}

Fresh leaves (1000 g) were cut into small pieces and subjected to hydrodistillation for $3 \mathrm{~h}$, using a Clevengertype apparatus. The oil (0.3 - $0.5 \%$ yield) was dried over anhydrous sodium sulphate and stored at $4{ }^{\circ} \mathrm{C}$ (Rojas et al., 1999).

\footnotetext{
*Corresponding author:

Flor Dolveni Mora, Departamento de Farmacognosia y Medicamentos Orgánicos/ Facultad de Farmacia y Bioanalisis/Universidad de Los Andes/Mérida/ Venezuela. E-mail: flormv@ula.ve
} 


\section{Gas chromatography (GC)}

GC analyses were performed using a Perkin-Elmer AutoSystem gas chromatograph equipped with a flame ionization detector and data handling system. A 5\% phenylmethyl polysiloxane fused-silica column (AT-5, Alltech Associates Inc., Deerfield, IL), $60 \mathrm{~m} \times 0.25 \mathrm{~mm}$, film thickness $0.25 \mu \mathrm{m}$, was used. The initial oven temperature was $60^{\circ} \mathrm{C}$; it was then heated to $260^{\circ} \mathrm{C}$ at $4^{\circ} \mathrm{C} / \mathrm{min}$, and the final temperature maintained for $20 \mathrm{~min}$. The injector and detector temperatures were $200^{\circ} \mathrm{C}$ and $250^{\circ} \mathrm{C}$, respectively. The carrier gas was helium at $1.0 \mathrm{~mL} / \mathrm{min}$. The sample $(1 \mu \mathrm{L})$ was injected using a Hewlett-Packard ALS injector with a split ratio of 50:1. Retention indices were calculated relative to $\mathrm{C} 8$-C24 $n$-alkanes, and compared with values reported in the literature (Adams, 2007; Davies, 1990).

\section{Gas chromatography-mass spectrometry (GC-MS)}

GC-MS analyses were carried out on a Model 5973 HewlettPackard GC-MS system fitted with a HP-5MS fused silica column $(30 \mathrm{~m} \times 0.25 \mathrm{~mm}$ i.d., film thickness $0.25 \mu \mathrm{m}$, Hewlett-Packard). The oven temperature program was the same as that used for the HP-5 column for GC analysis; the transfer line temperature was programmed from $150^{\circ} \mathrm{C}$ to $280^{\circ} \mathrm{C}$; source temperature, $230^{\circ} \mathrm{C}$; quadrupole temperature, $150^{\circ} \mathrm{C}$; carrier gas, helium, adjusted to a linear velocity of $34 \mathrm{~cm} / \mathrm{s}$; ionization energy, $70 \mathrm{eV}$; scan range, 40:500 amu; 3.9 scans/s. The sample was diluted with diethyl ether $(20 \mu \mathrm{L}$ in $1 \mathrm{~mL})$ and $1 \mu \mathrm{L}$ was injected using a Hewlett-Packard ALS injector with a split ratio of 50:1. The identity of the oil components was established from their GC retention indices, by comparison of their MS spectra with those of standard compounds available in the laboratory, and by a library search (Nist, 05) (Adams, 2007; Davies, 1990).

\section{Bacterial strains and antibacterial assays}

The inhibitory activity of essential oil of M. parvifolia was tested against Gram-positive (Staphylococcus aureus ATCC 25923 and Enterococcus faecalis ATCC 29212) and Gramnegative (Escherichia coli ATCC 25922, Klebsiella pneumoniae ATCC 23357, and Pseudomonas aeruginosa ATCC 27853) strains provided by the Department of Microbiology and Parasitology, Faculty of Pharmacy and Bioanalysis, University of Los Andes). The antibacterial activity was performed according to the agar diffusion method with disks (Velasco et al, 2007). Ciprofloxacin was used as positive control. Assays were performed in duplicate.

\section{RESULTS AND DISCUSSION}

Hydrodestilation of $M$. parvifolia leaves produced slightly yellow oil which yielded from $0.3-0.5 \%$. The analysis of the essential oils obtained by GC-MS enabled the identification of the compounds, which are shown in
Table 1 and represented $97.31,96.37$ and $96.06 \%$ of the samples A, B and C respectively (Fig. 1). No significant differences were found in the composition of the oil from the three samples. More than $65 \%$ of the samples consist of two compounds: $\alpha$-bisabolol and $\alpha$-pinene. In this work, no antibacterial activity was observed against the tested bacteria. However, bisabolol as the major component of this oil has been tested for anti-inflammatory (Rocha et al, 1011), and antibacterial activity against some specific strains. Also it is known for its deodorizing effect (Forrer et al, 2013). a-Pinene has been found in several essential oils with antimicrobial activity (Rivas, 2012; Hernandez, 2013). Our results lead us to suppose that the a-pinene has an antibacterial synergistic effect for compounds with antibacterial activity. a-Pinene in combination with bisabolol seems not to have this effect or the enantiomeric non active form of this compound is in the oil. Further

Table 1: Chemical composition of the essential oil of Morella parvifolia samples A, B and C $\left(^{*}\right)$

\begin{tabular}{|c|c|c|c|c|}
\hline \multirow[t]{2}{*}{ Compound } & \multirow[t]{2}{*}{ LRI } & \multicolumn{3}{|c|}{ Peak area percent } \\
\hline & & A & B & $\mathrm{C}$ \\
\hline 3-hexenol & 849 & 0.29 & 0.12 & - \\
\hline$\alpha$-thujene & 931 & 0.23 & 0.32 & 0.28 \\
\hline$\alpha$-pinene & 937 & 12.88 & 16.48 & 16.79 \\
\hline benzaldehyde & 941 & - & 0.15 & - \\
\hline camphene & 952 & 0.25 & 0.40 & 0.41 \\
\hline$\beta$-pinene & 978 & 0.70 & 1.00 & 0.96 \\
\hline$\alpha$-terpinene & 1013 & - & 0.25 & 0.16 \\
\hline$p$-cymene & 1015 & 3.18 & 3.91 & 4.98 \\
\hline limonene & 1025 & 2.16 & 3.11 & 3.03 \\
\hline 1,8-Cineol & 1033 & - & 0.15 & 0.16 \\
\hline$\gamma$-terpinene & 1061 & 3.58 & 5.14 & 4.11 \\
\hline$\alpha$-terpinolene & 1090 & 0.37 & 0.6 & 0.47 \\
\hline linalool & 1100 & 2.62 & 2.68 & 2.76 \\
\hline nonanal & 1104 & - & 0.16 & 0.17 \\
\hline borneol & 1159 & - & 0.24 & 0.25 \\
\hline terpineol-4 & 1155 & 0.34 & 0.42 & 0.37 \\
\hline$\alpha$-terpineol & 1178 & 0.64 & 0.76 & 0.72 \\
\hline fenchyl acetate & 1205 & - & 0.23 & 0.28 \\
\hline bornyl acetate & 1293 & 0.38 & 0.42 & 0.49 \\
\hline eugenol & 1331 & 0.95 & - & 0.83 \\
\hline E- caryophyllene & 1434 & 2.15 & 2.25 & 1.55 \\
\hline$\alpha$-bergamotene & 1434 & 0.60 & 0.56 & 0.50 \\
\hline ar-curcumene & 1484 & - & 0.13 & 0.14 \\
\hline$E-\beta$-farnesene & 1486 & 0.68 & 0.58 & 0.51 \\
\hline$\alpha$-zingiberene & 1496 & - & 0.15 & - \\
\hline$\beta$-bisabolene & 1510 & 0.54 & 0.45 & - \\
\hline (Z)- $\alpha$-bisabolene & 1542 & 2.22 & 1.78 & 1.56 \\
\hline caryophyllene oxide & 1578 & 0.63 & 0.49 & 0.65 \\
\hline$\beta$-eudesmol & 1641 & 0.33 & - & - \\
\hline bisabolol oxide & 1654 & 2.67 & 2.22 & 3.37 \\
\hline$\alpha$-bisabolol & 1689 & 58.92 & 51.22 & 50.56 \\
\hline Total & & 97.31 & 96.37 & 96.06 \\
\hline
\end{tabular}

$\left.{ }^{*}\right)$ The chemical composition was determined by comparison of mass spectra of each compound database Wiley GC/MS library and Kovats index (LRI). Kovats index were determined on HP-5 capillary column 


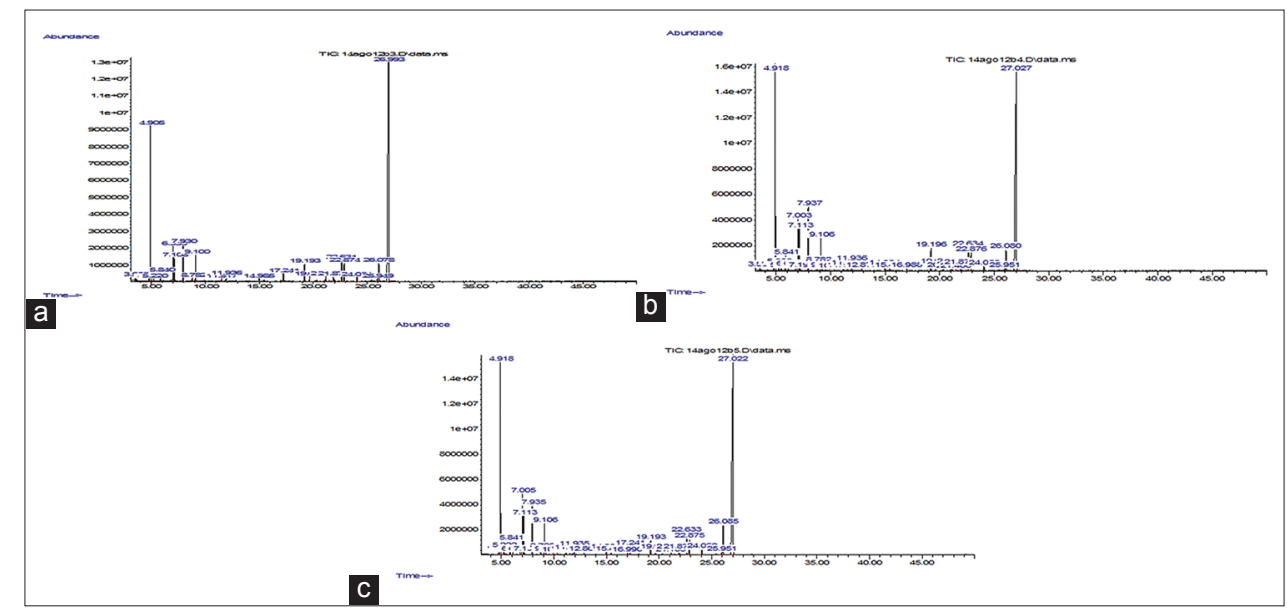

Fig 1. Chromatograms of the essential oil of Morella parvifolia, a) sample A, b) sample B, c) sample C

investigations are necessary to determine the antibacterial activity of these compounds, either pure or combined.

\section{CONCLUSION}

According to the results observed in this study, the essential oil of Morellaparvifolia from the Venezuelan Andes (Mérida State) has a chemical composition with high content in monoterpenes and sesquiterpenes. The major compounds found in the oil were: $\alpha$-bisabolol and $\alpha$-pinene. No microbiological activity against selected Gram (+) and Gram (-) strains was determined. This study contributes to the knowledge of chemical components and biological activity of the essential oil of this specie.

\section{Authors contribution}

M.F.D. wrote the project, obtained the essential oil and chemical analysis, H.V. performed antimicrobial activity, C.J. and S.B. did the taxonomic identification and collect the specie, R.L.B. Chemical analysis of the essential oil using gas chromatography and mass spectrometry. All authors wrote, read and approved the final manuscript.

\section{ACKNOWLEDGMENTS}

The authors would like to thank Dr. Alfredo Usubillaga and Dr. Rosa Aparicio for collaboration with GC-MS analysis

\section{REFERENCES}

Adams, R. 2007. Identification of Essential oils Components by Gas Chromatography/Mass Spectroscopy. $4^{\text {th }}$ ed. Allured Publishing, Corporation, Carol Stream IL, USA, p. 804.

Davies, N. 1990. Gas chromatographic retention indices of monoterpenes and sesquiterpenes on methyl silicone and Carbowax 20 M phases. J. Chromatogr. A. 503: 1-24.
Forrer, M., E. M. Kulik, A Filippi and T. Waltimo. 2013. The antimicrobial activity of alpha-bisabolol and tea tree oil against Solobacterium moorei, a gram-positive bacterium associated with halitosis. Arch. Oral. Biol. 58: 10-6.

Hernández, V., F. D. Mora, M. C. Araque, L. B. Rojas, P. Meléndez and $\mathrm{N}$. de Tommasi. 2013. Composición química y actividad antimicrobiana del aceite esencial de Astronium graveolens Jacq de la reserva forestal de Caparo, Venezuela. Rev. Lat. Quim. 41: 89-94.

Hokche, O., P. E. Berry and O. Huber (Eds.). 2008. Myricaceae. Nuevo Catálogo de la Flora Vascular de Venezuela. Fundación Instituto Botánico de Venezuela, Venezuela, Caracas, Pp. 1-860.

Jorgensen, P. M., and C. Ulloa. 1994. Seed plants of the high Andes of Ecuador - A checklist. AAU Rep. 34: 1-443.

Luteyn, J. L. 1999. Páramos, a checklist of plant diversity, geographical distribution, and botanical literature. Mem. NY. Bot. Gard. 84: VIII-XV, 1-278.

Parra, O. C. 2002. New combinations in South American Myricaceae. Brittonia. 54: 322-326.

Rivas da Silva, A. C., P. M. Lopes, M. M. Barros de Azevedo, D. C. Costa, C. S. Alviano and D. S. Alviano. 2012. Biological activities of $\alpha$-pinene and $\beta$-pinene enantiomers. Molecules. 17: 6305-6316.

Rocha, N., E. Rios, A. Carvalho, G. Cerqueira, A. A. Lopes, L. Leal, M. Dias, D. de Sousa and F. de Sousa. 2011. Anti-nociceptive and anti-inflammatory activities of (-)-a-bisabolol in rodents. Naunyn Schmiedebergs Arch. Pharmacol. 384: 525-533.

Rojas, L., A. Usubillaga and F. Galarraga. 1999. Essential oil of Coespeletia timotensis. Phytochemistry. 52: 1483-1484.

Sandra, P. and C. Bicchi. 1987. Capillary Gas Chromatography in Essential Oil Analysis. Huethig, Heidelberg.

Sandoval, J., C. Quijano, G. Morales and J. Pino. 2010. Composition of the essential oil from the Leaves and fruits of Morella pubescens (Humb. et Bonpl. ex Willd.) Wilbur grown in Colombia. J. Essent. Oil Res. 22: 133-134.

UNEP-WCMC. 2010. A-Z Guide to Areas of Biodiversity Importance. UNEP-WCMC. Cambridge, UK. Available from: http://www. biodiversityA-Z.org. [Last accessed on 2014 Feb 19].

Velasco, J., J. Rojas, P. Salazar, M. Rodríguez, T. Díaz, A. Morales and M. Rondón. (2007). Antibacterial activity of the essential oil of Lippia oreganoides against multiresistant bacterial strains of nosocomial origin. Nat. Prod. Commun. 2: 85-88. 